ず,レスピレーターは 9 時間の後停止した．同様に肺高 血圧症を呈していたが，低肺血管抵抗比のため，経過観 察中であったが，肺炎による呼吸困難が著明となったた め, 生後 9 力月, 体重 $7.1 \mathrm{~kg}$ で, 完全体外循環時泊 動流を使用して手術を行った。前者と同様好 結果を得 た。

\section{結論}

体重 $10 \mathrm{~kg}$ 以下の equivaent PH 症例に対し, 体外 循環に拍動流を使用すると，術後肺合併症を予防し，好 結果が得られる.

\title{
3. 手術成績について
}

\section{主題 II-A-10 手術成績からみた手術方針の検討}

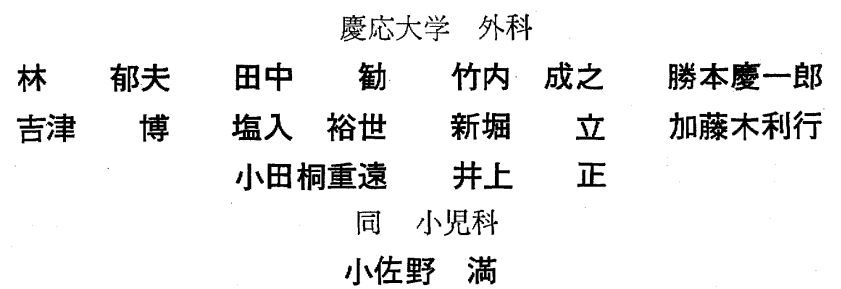

教室における $\mathrm{Pp} / \mathrm{Ps} 0.80$ 以上の VSD 根治術成績 は, 1970 年を境にして大きく変わっている. 即ち 1970 年以前（前期）では，35 例中 11 例 (31\%) が手術死亡 したが，一方 1971 年以降 (後期) では 53 例中 1 例（2 \%）の手術死亡だった。

この後期の成績は, 前期の症例の分析と反省に基づく おのである.

\section{前期の反省}

(1) Rp/Rs 0.75 以上の例 : 0.75 以下 25 例中 6 例死亡 飞対し，0.75 以上 10 例中 5 例 $(50 \%)$ の死亡. (2)心 尖部に diastolic rumble の聴取されない例 : rumble $(+)$ 例 25 例中 3 例死亡に対し, rumble (-) 例 10 例中 8 例 $(80 \%)$ の死亡. (3)胸部レ線上左室拡大像がな いか，めって子軽度な例：拡大像（卅）例 $17 \cdot$ 例中 3 例 死亡に対し, 挔大像 $(+) \sim( \pm)$ 例 18 例中 8 例 $(45 \%)$ の死亡. (4) $100 \% \mathrm{O}_{2}$ 吸入により $\mathrm{PA}$ 圧下降の不十分な 例 : 10 例中 7 例 $(70 \%)$ 死亡. (5) Kinklin 分類の III 型 に相当する例：I 型 9 例中死亡 0 , II 型 19 例中死亡 6 例, III型 7 例中死亡 5 例.

以上 5 群に手術死亡の多いことが判明した.

\section{後期の方針}

予定手術は原則として 1 才から 3 才頃まで行うもの の, 心尖部 diastolic rumble の減弱傾向, 胸部レ線上 左室拡大像減少傾向が現われた場合は直ちに手術を行 5. Kirklin II ・ III型に対しては術後の右室機能に与兄 る影響を考慮し，可及的に経右房より修復を行なう。

また乳児期手術に関しては，1才未満で小児心蔵外来， を受診する心不全を伴う VSD+PH の約 17\% が，自 然閉鎖あるいは手術適応外となる程軽症化するという自 然歷を考慮し, 重篤な心不全や呼吸器感染をくり返兄し 内科的治療が困難な場合に限り，乙か子一期的に根治術 を行なう。肺動脈较約術は行なわない。

\section{後期の手術成樍（表 1 )}

$\mathrm{Pp} / \mathrm{Ps} 0.80$ 以上 53 例中, equivalent $\mathrm{PH} \mathrm{Pp} / \mathrm{Ps} \div 1.0$ は 18 例で，手術死亡は 1 例だった。手術時年令は，1

図 $1 \mathrm{Pp} / \mathrm{Ps}$ と手術成績

$(\mathrm{Pp} / \mathrm{Ps} \geqq 0.80$ の VSD) $1971 \sim 1976$

\begin{tabular}{ll}
$\leqq 0.95$ & $\doteqdot 1.0$ \\
\hline $35(0)$ & $18(1)$ \\
\hline & $($ ) 死亡
\end{tabular}



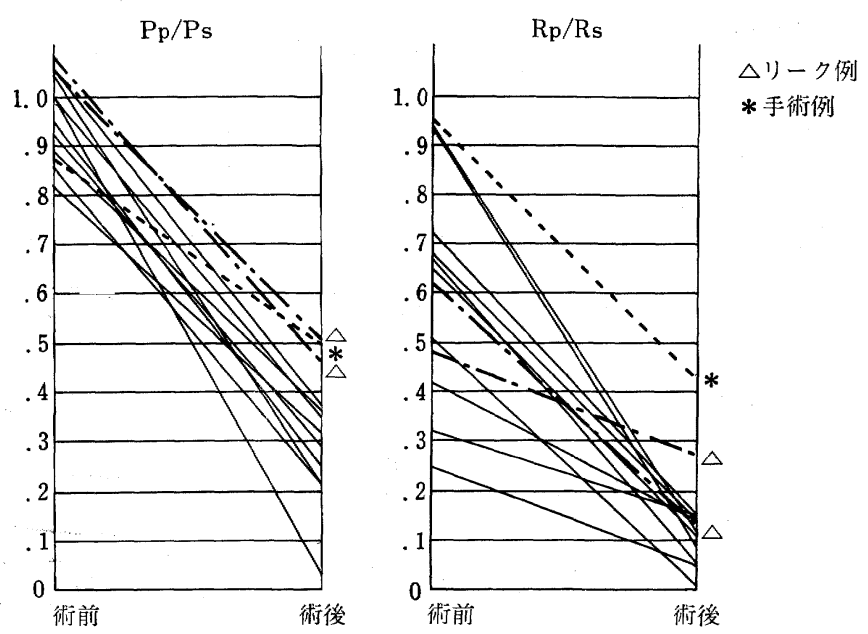

図 術後 PH の変動

才末満 3 例， 1 才から 3 才台末で 30 例 4 才以上が 20 例だった，遠隔死亡は severe PH 例に 1 例あるが，心 葴死ではなかった. 更に equivalent $\mathrm{PH}$ 症例中 $\mathrm{Rp} / \mathrm{Rs}$ 0.75 以上は 4 例だった。

\section{術後経過時における PH の变動（図 1 )}

術後の心力テは後期例では 10 力月以後 2 年目位まで に行っているか, $\operatorname{Pp} / \mathrm{Ps} \cdot \operatorname{Rp} / \operatorname{Rs}$ とも著明に改善してお り，特に $\operatorname{Rp} / \operatorname{Rs}$ は正常域に戻っている。 $\Delta$ 印はリーク 例で, 再力テ時期も 2 力月， 8 力月と早い. 再手術後臨 床的には何の問題もない.一方*印は 5 才で手術を行っ た例で $\mathrm{P}_{\mathrm{p}} / \mathrm{Ps}_{\mathrm{s}} \cdot \mathrm{Rp} / \mathrm{Rs}$ とも改善度が低くなって括り，手 術時期の拈くれを示していると考えている。

\section{予定手術を 1 才から 3 才頃までとした根掤}

不可逆性 $\mathrm{PH}$ と診断された例の初回力テ年令をみる と, 1976 年末までに 4 才以降 23 例を数光得るが. そ れ以前には1才 8 力月の primary $\mathrm{PH}$ と考觉られる 1 例をみるのみである（その 1 例は心雑音を強く指摘され たりしたことはなく，かつ心不全の既往もなく，アンギ オ上 PA 本梢性狭窄を来たしている). このことから,
専問医による乳児期からの一貫した経過観察の重 要 性 と, $\mathrm{VSD}+\mathrm{PH}$ は遅くとも 3 才頃までに手術すれば，肺 血管の不可逆性閉塞病変への進展はまぬがれ得るという ことがいえるのではないかと思う。

\section{$\mathbf{L} \rightarrow \mathbf{R}$ 短絡が著明に減少した場合の手術適応}

症例は equivalent $\mathrm{PH}$ で, 生後 2 力月時行った心力 テでは $\mathrm{L} \rightarrow \mathrm{R}$ 短絡率 63\%であったが, 呼吸器感染をく り返えし, 感染時には diastolic rumble 6消失し, チ アノーゼも出現した. 比較的良い時期の再力テでも $\mathrm{L} \rightarrow$ $\mathrm{R}$ 短絡率 $0 \%, \mathrm{R} \rightarrow \mathrm{L}$ 短絡率 $30 \%$ で，この deta から では手術は全く考えられない:しかし心陰影も大きく， あきらめずに長期入院感染治療により diastolic rumble の聴取できる時期を選んで手術を行ったところ, 肺生検 でも H-E 1 度の結果を得, 無事根治することができ た.

このように，単にカテ計算 deta から手術適応をいわ ずに，各種臨床所見を総合して適応を決定することは特 に強調したいことの一つである、くり返えし行なう心力 テ, 更に肺生検の結果も大変参考になると思われ, 実施 している。 